\title{
WAR MINERALS.
}

\author{
J. E. SpUrR.
}

The interest of economic geologists and mining engineers in these days is centered on the problem as to how they can be of maximum service to the country in this time of the nation's supreme effort. The application of geology to military affairs has been considerably debated and we believe that a study on this subject would constitute an interesting contribution to the pages of this journal. All forms of engineering are of great immediate importance in military operations, as has been recognized by the formation of separate engineering units in the army, including that of the mining engineers. The work which the mining engineers perform in the army is, however, one that often has little to do with applied geology.

Leaving out of the question the debatable problem as to the degree of practicability of the application of geology to military campaigning, it is clear that the mining geologist and the practitioner of the other forms of applied geology has a great usefulness in bringing about greater efficiency in the affairs of the nation in the department in which he is proficient. In time of war the affairs of life and of the nation are constantly separated into essentials and non-essentials and articles of production into necessities and luxuries, and any essential business which deals with necessities becomes a war industry and the application of economic geology to any of these becomes an application of economic geology to military affairs. Since the nation is essentially an armed camp and the necessary industries are as actually a part of the campaigning and can no more be dispensed with than can the supply and hospital units be dispensed with in the army in the field, it therefore results that where a mining geologist or mining engineer is engaged in such a way that he is increasing the production of a necessary metal he is virtually doing more effective 
military work than if he were in uniform. He is a trained officer in the great industrial army which forms the reserve and the supply organization for the field army, and which provides for this advance army, arms, munitions and other necessities.

During peace times, when commerce is uninterrupted, the relative importance of certain metals within the United States is not a question which assumes great importance in our eyes, for what we do not have at home we can get abroad and sometimes more cheaply. But when our sources of supply in certain countries from which we are accustomed to draw are shut off by our being at war with them and where other sources of supply are restricted on account of the scarcity of shipping requiring curtailment of imports, it begins to be understood what vital strength there is in having great metallic resources within our boundaries and how great an importance lies in their being discovered, classified and developed. We have gone a certain distance in this work of adjustment but we can go very much further if necessary. It is in this adjustment work that the services of economic geologists can be of great value. The work of the writer has brought him within close touch with these problems and it is thought that a very brief synopsis of the situation, in regard to our principal war minerals (meaning by this term those minerals in regard to which the war brings up new problems of supply), would be of interest and would perhaps serve some good end. In the following paragraphs, therefore, minerals will be taken up alphabetically and a few words of description offered as to the war problems involved. These notes cover a few of the principal features of a study of war minerals undertaken for the United States Shipping Board in coöperation with C. K. Leith.

Antimony.-The United States is depending apon oversea imports for antimony, which is used in making shrapnel bullets. Should a satisfactory substitute for antimony be developed for hardening lead it may be possible to reduce these imports. Domestic deposits, so far as known, are limited.

Arsenic.-The United States imports arsenic principally for use as an insecticide. There is no scarcity of arsenical ores in the United States, but the arsenic in these ores has hitherto 
mostly been blown up the smelter stacks and wasted. It is understood that this will be corrected in the future. No particular geological problem is offered here, but the question is one of smelter practice.

Asbestos.-Although the United States has very little asbestos its good neighbor Canada has abundance for all purposes. It would be of interest, however, if a workable deposit of the socalled blue asbestos or crocidolite could be found either in the United States or Canada. The demand for this is small but imperative and this variety is now imported from South Africa.

Bauxite and Aluminum.-There are large deposits in Georgia, Alabama, Arkansas and Tennessee, and the United States has always supplied its own material. The aluminum industry, however, has had an immense growth and it is looking forward to securing a supply more and more in the future from outside sources, since the American resources will apparently not be sufficient. Further discoveries of bauxite would be of great interest. The demonstration of the practicability of manufacturing aluminum from other materials than bauxite would be revolutionary in the industry.

Bismuth.-Very little bismuth is used in this country and most of it is derived from the United States. This is a war mineral of no great importance.

Chalk.-We import great quantities of chalk from England. It is essential in many of its uses including the manufacture of whiting, as a filler in the manufacture of rubber goods, as a base for cold-water paints, in the manufacture of putty, in the glazing of porcelain and pottery, for moulds in brass foundries and for insulating purposes. We have in this country no material known to the trade in general which is equal to the imported article, and although importation of this material is conducted with very little loss of ship efficiency on account of its coming over as ballast in regular liners, it would still be a national asset to discover and catalogue a domestic material which would be a satisfactory substitute. The present substitute consists of domestic whiting manufactured from limestone and as a by-product in the manufacture of magnesium carbonate and this substitute, owing to the 
crystalline character, is not as desirable or as effective as chalk whiting.

Chromite.-Chromite is one of the most essential of war minerals on account of its use in hardening steel. It is an ore which is irregularly distributed and usually occurs in ore deposits of irregular form. The sources of the world's supply have fluctuated. Until the early part of the nineteenth century the world's supply came from Maryland and Pennsylvania until an American discovered chromite in Turkey. Thereafter for a long time the Grecian Archipelago supplied the world. More recently, with the increased demand for chromite due to the war, the principal sources have been in Rhodesia and in New Caledonia, both remote from the United States. Within the United States new fields have been discovered in California and Oregon, and in Canada in Quebec, and from these we have drawn part of our supply. Very recently, on account of the war emergency, chromite has been discovered, developed and to a certain extent mined in Brazil, Cuba and Central America.

The stimulation of the production of chromite in North America is one of the most patriotic services in which a mining geologist can engage. Certain economies are possible in the use of this ore and some of these have recently been brought about by government pressure. Still others can be brought about by further, more detailed and patient work on the part of the government. Economy in the use of materials containing chrome and in the use of chrome in the manufactures is a patriotic duty not in any way second to the saving of wheat. Steel companies have already arranged, as a result of government suggestion, to economize in the use of chromite in steel manufacturing. It is expected that economies in the use of chrome in the tanning of leather will be adopted as rapidly as possible. It is understood that the development of chromite fields in Cuba will be undertaken at once, which will take some of the burden off shipping required to bring ore from Brazil and New Caledonia. The developments already made in this direction have made possible the program of limiting, for the present, further importations from New Caledonia; a program which has been acquiesced in by 
the various government departments and by the steel and chemical industries. The stimulation of the production of the Cuban deposits would be as much a patriotic service as that of the domestic or Canadian deposits. Similarly there are chromite fields in Newfoundland and the stimulation of the production of these fields so far as feasible would be of great value.

Clay.-One of the most important of our war minerals is clay of the finer variety which is imported in large quantities for use in making china, porcelain, paper filler, paper coating, tiles, sanitary ware, oil cloth, etc. The importation comes from England in special cargoes and domestic manufacturers of these commodities have been unable, hitherto, to use more than a certain proportion of domestic clay mixed with the imported article. It is, therefore, necessary to continue importation.

There is a wide scope of usefulness for the economic geologist and technologist in this field of clays. He may engage in work on problems leading towards the greater utilization of domestic clay instead of the imported article for various uses which have hereto been depending upon the latter. Like all our other industries these clay-using industries are largely empirical and will not change their ancient formulas upon which they have built up a successful business unless under some strong pressure or shock, although this condition is being ameliorated by modern ceramic technology. Before the war a certain clay which came from Germany was held to be absolutely indispensable in the manufacture of graphite crucibles, but since the war the production of graphite crucibles using domestic clay as bond material has continued without serious interruption.

Correspondence with the users of imported English clay for the industries above specified elicits the fact that in certain cases a way has been found to utilize domestic material, although in other instances the substitution would be more difficult, as in the case of electric porcelain. Tiles and sanitary porcelain represent a field where some manufacturers use the domestic and some the imported article, and the latter cling very closely to their methods.

Another service, and one for which geologists are fitted, is the location and bringing to notice of deposits of clays in other parts 
of the country than those in which the present mines are situated. All domestic clay of the higher class comes at present chiefly from Florida, Georgia and South Carolina and the problem of transportation of the large tonnage of this material to the northern points where it is utilized is almost as great a one, involving the tax on the railroads that it does, as is the shipping of the imported article. The use of clay as a paper filler, for example, is one which absorbs the larger portion of the imported clay and moreover the paper mills are situated at some distance from the domestic deposits. New finds of clay suitable as paper filler in the northern states near the paper factories would be of great value, or the location of other deposits which could be used as a paper filler, such as talc.

Copper.-Copper is a war mineral of which we have a scant sufficiency and any mining geologist who is engaged in copper mines is probably doing as much for his country as he can do anywhere. We are moreover obliged to import copper metal and matte from some distance by water as, for exaniple, from Chile and Japan, and the larger the production of domestic copper, the less necessary would be these oversea imports with the attendant use of shipping needed for trans-Atlantic purposes.

Cryolite.-Although cryolite is a war mineral, it is not very important, and it is perhaps hardly proper to mention it in this particular, as it does not occur except in Greenland. Nevertheless we are obliged to mport a small quantity of this mineral for use in the manufacture of aluminum, but its place will soon be entirely taken by the artificial cryolite which is now being manufactured in larger quantity than the amounts of the natural ore which are imported.

Flint-Grinding Pebbles.-We have no satisfactory domestic substitute, so far as known, for the flint-grinding pebbles which we import from Denmark and from France. These are used in cement works, in metal mines and for grinding feldspar and silica for making chinaware, for grinding colors, etc. We have certain deposits of domestic pebbles which have been used for less delicate purposes, such as in the milling of ores and in cement works. Nearly all these pebbles contain impurities, especially iron, which 
makes their use impossible in uses like that of grinding silica and feldspar for the pottery trade and making electric porcelain, and grinding materials used in making lenses and chemicals. Most of the metal mines can get along without the imported pebbles if necessary and the cement mills could, like the mines, mostly substitute steel balls; but, with the present scarcity of steel, this is hardly a desirable substitute, from the war mineral standpoint.

Voluntary economy and employment of substitutes for imported flint pebbles for grinding purposes on the part of mining geologists and mining engineers would, again to quote our former language, be a saving equal in patriotic value to the saving of wheat, provided the substitutes come from some nearby region and reduce the strain upon our transportation facilities by sea or land. Geologists should bring deposits of pebbles which seem to be of value in this respect to the attention of users in their neighborhood, for the purpose of experiment.

Fuller's Earth.-Most of the fuller's earth used in the United States is a domestic product, but in I9I7 we imported something over I5,000 tons from England. The imported fuller's earth is used exclusively in bleaching of edible oils including olive oil, cottonseed oil and lard. Eighty per cent. of the fuller's earth produced in the United States comes from Florida and is used in filtering lubricating oils. Deposits of fuller's earth suitable for bleaching purposes occur in Texas and Georgia and have been used as a substitute for the imported article. Some of the largest manufacturers of edible oils use domestic and some insist upon the necessity of the imported material. Deposits of fuller's earth should be investigated. Wherever a source of domestic supply can be used which will reduce the transportation necessary for the imported article or for the domestic earth found in the south, a great help will be made toward the industrial efficiency of the country.

Graphite.-We have considerable deposits of domestic graphite, principally in Alabama. The flake, however, is a small one and not esteemed very highly by domestic manufacturers of graphite crucibles, which are used in the manufacture of crucible steel. Nevertheless, tests show that satisfactory crucibles can be 
made from it. Domestic crucible makers prefer the graphite from Ceylon, but the British and French manufacturers use that which comes from Madagascar. The importation of Ceylon graphite has been restricted and if close attention is paid to the preparation of domestic graphite for the market it should in time overcome the prejudice of the crucible manufacturers and become a substitute for the imported article. In the past these prejudices have been very well founded on account of lack of care, in numerous cases, on the part of the producers. Domestic graphite is largely used for other purposes than crucibles and will be used almost exclusively for this purpose until the end of the war.

Iron Ore.-Any mining geologist engaged in any part of the great work of producing iron ore can scarcely be in a more serviceable occupation.

Magnesite.-Before the war the United States consumed about 300,000 tons of magnesite annually, of which about 290,000 tons were imported. Of the imported material, that suitable for refractory purposes was imported from Austria-Hungary, and a pure fine grade of magnesite imported from Greece was used for plastic purposes such as flooring. With the cutting off of former supplies, magnesite deposits were fortunately discovered and developed in California and Washington. California produced 250,000 tons of magnesite in I9I7 similar to that formerly imported from Greece, and Washington produced about I00,000 tons of the crystalline variety suitable for refractory purposes in 1917. It is estimated that these deposits can double their output in 1918. Due to these new industries it has become possible entirely to dispense with the importation of magnesite. This is an essential war mineral, especially as it is being used to take the place of chromite as a refractory and is an essential part of the economic program entered into by the steel corporations, in consequence of government representations.

Manganese.-No war mineral has a greater importance than manganese on account of its use in steel manufacturing, hardening steel for war, and other essential purposes.

With the cutting off of manganese from Russia by the war and the subsequent shortage of imports of manganese from 
India on account of decreased shipping, the bulk of the highgrade ore has been lately drawn from Brazil. We have not in this country sufficient high-grade ores to make high-grade ferroalloys from ferromanganese. Nevertheless, the present stringency in shipping has made it necessary to reduce the importations of manganese to the lowest possible point and the steel manufacturers, under government advice, have entered into a campaign of economy involving a maximum use of domestic ores such as are fitted for the lower-grade alloy called spiegeleisen. The maximum production of domestic manganese of all grades is one of the most urgent things in the war, especially as difficulties of labor and transportation threaten this as well as other essential industries which run up into large tonnages. No greater service could be rendered by mining geologists than to assist in any way in the production of domestic manganese ore, or by metallurgists than in devising and practicing increased economies and a larger use of the low-grade alloy in the steel manufacture. In this matter nearly every section of the country has its interests and possibilities.

Mercury.-The United States produces its own requirements of mercury and has some left over to ship our Allies. This is an important war mineral and domestic production should be maintained. Mining geologists should keep this in mind and do what they can to increase the production when the matter is brought before them.

Mica.-Mica is an essential war mineral on account of its use in making electrical apparatus. We import a higher grade of mica for this purpose, largely from India, although we have some high-grade mica in this country which is used for electrical purposes, for example, some of that which comes from New Hampshire in the vicinity of Keene. The Indian mica is valued by the trade on account of its pliability and the fact that it is standardized better than the domestic article. A certain amount of mica has also come in from Brazil on account of the supply from India being difficult to obtain.

Deposits of sheet mica should be carefully examined and tested to see whether it is satisfactory for the more exacting uses and 
can be produced commercially. The increase of a supply of our domestic mica of higher grade would relieve us of the necessity of importation, although the tonnage is a small one.

Monazite.-Monazite is used in the manufacture of thorium, which is used in making incandescent mantles for gas burners. These are considered a war necessity, as specially demonstrated in England, where the manufacture of toluol from illuminating gas has greatly reduced the illuminating power and necessitated the employment of these mantles. A by-product of the thorium manufacture is mesothorium, used in the manufacture of luminous paints and in other ways as a substitute for radium.

We import nearly all our monazite from India and Brazil. Deposits of monazite sands occur in North Carolina and Florida but cannot compete commercially with the imported article and are very much lower grade. Labor conditions are very bad in the domestic monazite districts and no considerable amount of monazite could be produced at present except at an enormous price. All things considered, it seems best to regard our domestic monazite as a low-grade article which we may use in case of emergency, when it would be very valuable, and to conclude to husband our resources in this respect.

Nitrates.-Our importation of nitrates from Chile are enormous. Although most of the material imported is used for the manufacture of explosives, a large quantity is used for agricultural purposes as a fertilizer. Most of the wheat and corn of the country are grown without the use of fertilizers and the same is true of more than half of the cotton crop. But other crops, such as the truck gardens and potato farms of the east and about half of the cotton plantations of the south, depend upon artificial stimulation of the soil. It is true that the continued growing of crops in the west without fertilizers cannot go on indefinitely and more and more a system of crop rotation or a more extended use of fertilizers will be required. At the present time, however, it is imperative that a minimum amount of nitrogen compounds necessary for explosives should be used for agricultural purposes.

There are large stores of organic nitrogen in cottonseed cake and meal, tankage, blood, fish scrap, etc., of domestic origin that 
can be advantageously mixed with acid phosphate rock. There is a growing opinion that the necessity and advantage of the great use of sodium nitrate and ammonia sulphate as fertilizer may have been overrated and that the necessary nitrogen can and should be found more in organic ingredients and that the permanent solution of the agricultural nitrogen problem may be found in the soil bacteria rather than in electro-chemistry.

It is most essential that in every way possible economy in the use of sodium nitrate and ammonia sulphate should be practiced and it would be a patriotic service for the farmers to do everything possible to minimize the use at the present time of inorganic nitrogen.

Platinum.-Platinum occurs in this country, but not in quantities sufficient to supply our demands, which have been met from Russia and to a smaller degree from Colombia. Platinum occurs in the United States in certain ores, as in Wyoming and California, and to a small extent in sands, as those of the Columbia River, and as a by-product in refining metals. Wherever possible the production of platinum should be increased. Platinum jewelry should not be purchased and any amount of platinum which may be held privately, no matter how small, should be turned over to the government.

Pyrite.-Pyrite, which with sulphur is used in the manufacture of sulphuric acid, is a very important war mineral. We have up to recently imported large amounts of pyrite from Spain. This importation has been cut down to a fraction of the usual amount and an effort is being made to produce sufficient domestic pyrite to make up the deficiency, together with the use of sulphur from the southern deposits in Louisiana and Texas. Those engaged in the production of pyrite should make every effort to see that this production is maintained and increased to the greatest possible extent, because upon this production will depend the feasibility of maintaining the present restriction of imports with its attendant ship saving, so vital in the present emergency.

Tin.-Tin in North America, as is well known, is sparse and of low grade and has yet to be of any commercial importance. Our demands for tin as a war mineral are very large. It is an 
essential, as it goes into the making of food containers which supply our army. The price of tin has increased very greatly on account of the demand for it and it is possible that in the near future conditions might be such that some of our domestic deposits might contribute something towards the general supply. The tin of the Seward Peninsula in Alaska appears to be the most promising locality. Any production which can be made from this or other regions will be of great help in the war program.

Tungsten.-Tungsten, which is used as a hardener of steel, is a war mineral of importance, and although deposits of this ore are scattered throughout the United States yet we do not produce sufficient for our own consumption and import something like 5,000 tons a year from other countries, principally from South America. The country is vitally interested in a larger production of tungsten ore in the United States which would remove the necessity of using shipping for importing it. Wherever geologists and mining engineers can assist in the production of tungsten they should regard it as a patriotic service.

Vanadium.-The above remarks on the subject of tungsten apply principally to vanadium also. We have domestic supplies of vanadium, but not enough is produced to satisfy our needs for the use of this material for war purposes as a hardener of steel; therefore we are obliged to import this ore from Peru to the extent of about 3,500 tons a year. Those owning vanadium prospects or able to engage in producing the ore should consider it a matter of duty to produce all that they can, because the shipping which brings this ore from the west coast of South America is barely sufficient for bringing in other commodities, such as nitrate, which we do not produce at all in this country.

We have gone over separately the different war minerals above mentioned and sketched very briefly their necessity for the reason that geologists and mining engineers are scattered all over the continent and anyone of them may, on occasion, find opportunity for increasing the production or even of finding new localities for some of these important materials and be enabled thereby to add his bit to the work which is going on for the common good. 